\section{Kentucky Bluegrass Thatch Characteristics Following Application of Bio-organic Materials}

\author{
W.L. Berndt ${ }^{1}$, P.E. Rieke ${ }^{2}$, and J.M. Vargas, Jr. ${ }^{3}$ \\ 102 Pesticide Research Center, Michigan State University, East Lansing, \\ MI 48824
}

\begin{abstract}
Additional index words. cellulose, decomposition, earthworms, fiber, lignin, Poa pratensis, turfgrass
\end{abstract}

Abstract. Three bio-organic materials were evaluated at four application rates, based on $\mathrm{N}$ contents, for their potential to degrade Kentucky bluegrass (Poa pratensis L.) thatch in a field experiment. Treated thatch was reduced in thickness and had increased earthworm (Lumbricus spp. Hoff.) populations when compared to untreated thatch. Thatch thickness was negatively correlated with level of $\mathrm{N}(r=-0.91)$, thatch lignin content $(r=-0.94)$, and earthworm population in the thatch $(r=-0.64)$, and positively correlated with thatch cellulose content $(r=0.62)$.

Core cultivation combined with frequent topdressing has proven to be an effective thatch management procedure for creeping bentgrass (Agrostis palustris Huds.) turfs (Engel and Alderfer, 1967). Time and economic constraints may prohibit this approach for other turf situations, such as ornamental lawns. Martin and Beard (1975) studied the feasibility of using enzymes and carbon compounds to stimulate thatch microbial activity in a growth-chamber study. When they applied pectinase and ferulic acid to red fescue (Festuca rubra L.) thatch, microbial activity increased and total cell wall content of thatch decreased. Whether these compounds would effect microbial activity and thatch decay in situ was not determined.

Decomposing existing thatch by applying microbial inoculum has been investigated (Sartain and Volk, 1984). In a pot culture study, applying white rot fungi (Coriolus versicolor) to bermudagrass (Cynodon dactylon L. Pers.), centipedegrass (Eremochloa ophiuroides), St. Augustinegrass [ Stenotaphrum secundatum (Walt.) Kuntze], and Kentucky bluegrass reduced thatch, but the overall magnitude of decrease was not great. Murdoch and Barr (1976) tested commercial inoculum in situ for aiding thatch decomposition in common bermudagrass in Hawaii. They concluded that the inoculum was ineffective in reducing thatch after a 5-month test.

Several new thatch control products have recently been produced for use in turf. These are organic materials that can serve as complete fertilizers and are enriched with micro-

Received for publication 12 Dec. 1988. The cost of publishing this paper was defrayed in part by the payment of page charges. Under postal regulations, this paper therefore must be hereby marked advertisement solely to indicate this fact.

'Research Assistant, Dept. of Botany and Plant Pathology and the Pesticide Research Center.

${ }^{2}$ Professor, Dept. of Crop and Soil Sciences.

${ }^{3}$ Professor, Dept. of Botany and Plant Pathology and the Pesticide Research Center. organisms thought to stimulate thatch decay. We therefore termed these materials bio-organics. This research was initiated to evaluate the status of existing Kentucky bluegrass thatch after treatment with three bio-organic materials.

This study, was conducted on a Kentucky bluegrass turf ('Victa', 'Bristol', and 'Cheri') located at the Robert Hancock Turfgrass Research Center in East Lansing. The study was begun 20 Oct. 1984. Turf was established as sod in 1981. Sod was originally harvested from a Carlisle organic soil (euic, Typic Medisaprist). Experimental site subsoil was a disturbed clay loam with a $\mathrm{pH}$ in water of 8 and CEC of $9 \mathrm{cmol} \cdot \mathrm{kg}^{-1}$. Thickness of six random thatch samples from the experimental site measured $\approx 24$ to $25 \mathrm{~mm}$ before the study. Thatch had a C:N of $26: 1$ and a bulk density of $0.22 \mathrm{~g} \cdot \mathrm{cm}^{-3}$. Total carbon was determined by loss on ignition at $700 \mathrm{C}$ and total $\mathrm{N}$ determined by the microKjeldahl method excluding $\mathrm{NO}_{3}-\mathrm{N}$. Bulk density was determined gravimetrically and by calculating the volume of each thatch sample after drying, then averaging. Turf was mowed three times weekly at $5 \mathrm{~cm}$ with clippings removed. Broadleaf weeds were controlled with 2,4-dichlorophenoxyacetic acid (2,4-D) at $1.1 \mathrm{~kg} \cdot \mathrm{ha}^{-1}$ in Spring 1985 . Irrigation was supplied with weekly applications of $\approx 50$ to $70 \mathrm{~mm}$. The study area had been fertilized twice yearly at $50 \mathrm{~kg} \mathrm{~N} / \mathrm{ha}$ per application and was considered lowmaintenance before initiation of this study.

The materials, Lawn Restore (10\% N, 49\% C), Lawn Rx (3\% N, 37\% C), and C-50 $(10 \% \mathrm{~N}, 47 \%$ C) (Ringer, Minneapolis) consisted of various organic and inorganic constituents. Nitrogen and carbon contents were determined as described above. Exact compositions were trade secrets. Yeast (Torula spp.) was the predominant $\mathrm{N}$ source in all materials. C-50 also contained $13 \%$ of total $\mathrm{N}$ as $\left(\mathrm{NH}_{4}\right) \mathrm{SO}_{4}(21 \mathrm{~N}-0 \mathrm{P}-0 \mathrm{~K})$. The microbial inoculum consisted of unidentified soil bacteria, actinomycetes, and fungi with $\approx 600$ to $900 \times 10^{6}$ total organisms/g of material. Approximations were done by dilution plating on nutrient agar (for bacteria) or potato dextrose agar (for actinomycetes and fungi).

Experimental design was a randomized complete-block with three replications. Plot size was $2.23 \mathrm{~m}^{2}$. Treatments were arranged as a $3 \times 4$ factorial consisting of three materials applied at $0,97.6,195.3$, and 390.6 $\mathrm{kg} \mathrm{N} /$ ha per application. Experimental N levels in the study were considered excessive but necessary for a short-term study. Applications were made on 20 Oct. 1984, and on 15 May, 15 June, 15 July, and 20 Sept. 1985 using a hand-held shaker box. After application, treatments were irrigated with $\approx 25$ $\mathrm{mm}$ water.

On 25 Oct. 1985, six 10.8-cm-diameter samples per plots were collected to a depth of $10 \mathrm{~cm}$ with a cup cutter (Par Aid, St. Paul, Minn.). Samples, consisting of turf, thatch, and soil, were dried at $60 \mathrm{C}$ for $24 \mathrm{hr}$ in a

Table 1. Trend analysis summary for Kentucky bluegrass thatch thickness ${ }^{2}$, lignin contenty, cellulose contenty, and carthworm population ${ }^{x}$ as influenced by Lawn Restore, Lawn Rx, and C-50. Analysis was performed on the means of three observations across all $\mathrm{N}$ levels.

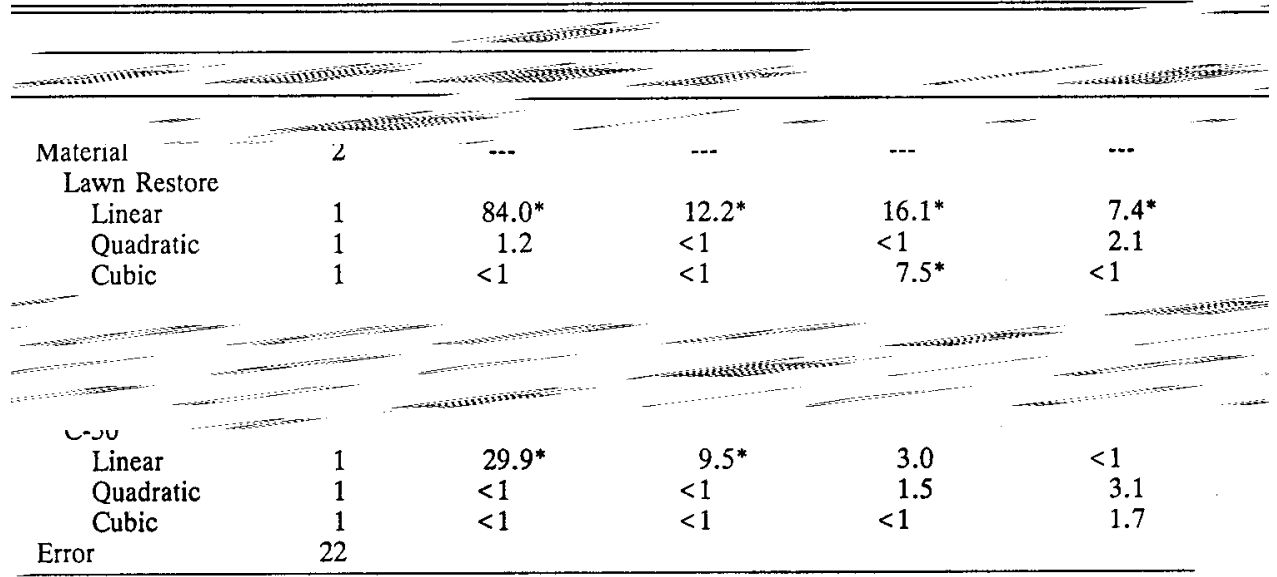




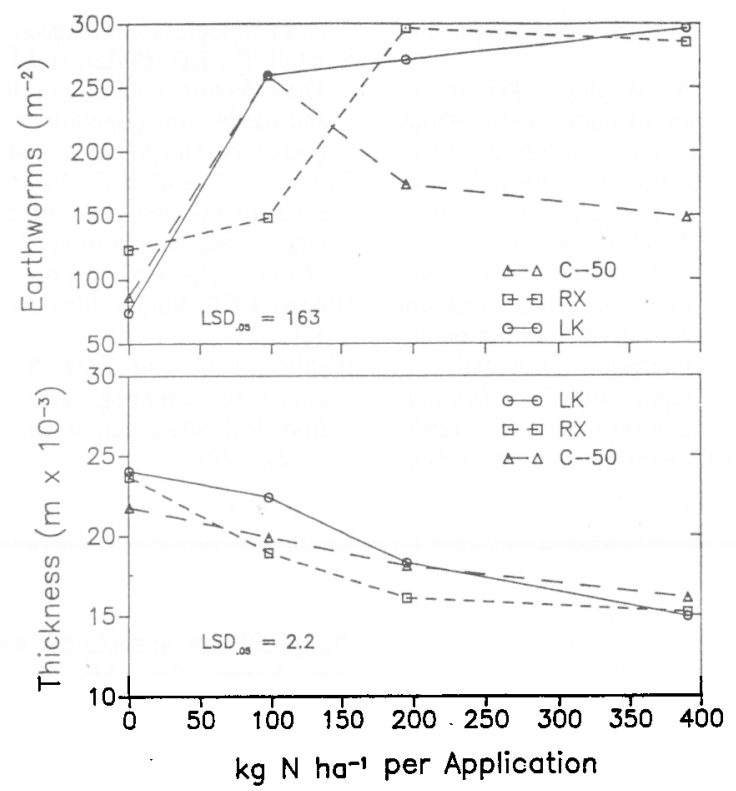

Fig. 1. Mean values for Kentucky bluegrass thatch thickness and thatch earthworm populations as influenced by Lawn Restore (LK), Lawn Rx (RX), and C-50. Data are the means of three observations. Thatch thickness values correspond to millimeters of processed thatch. Earthworm populations are per square meter of thatch only.

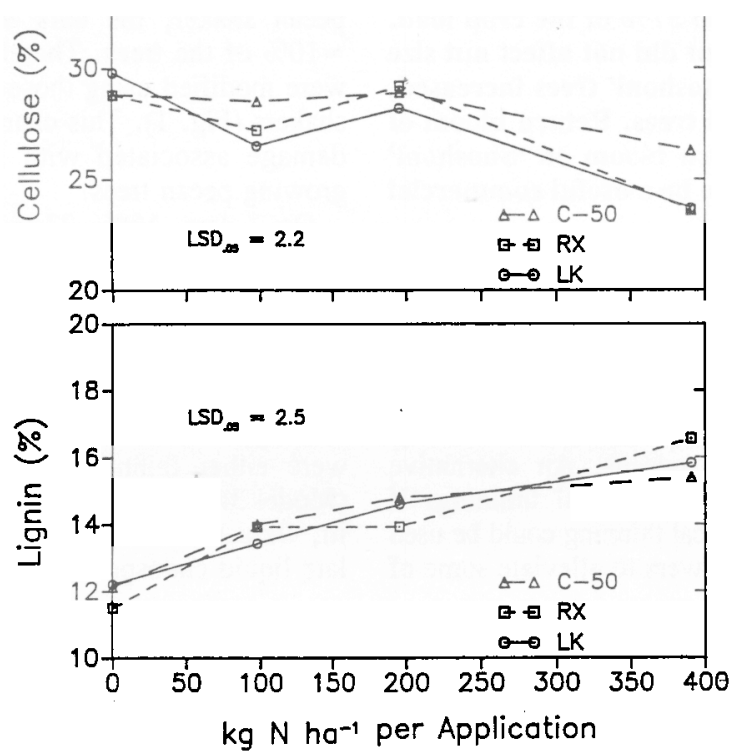

Fig. 2. Mean values for Kentucky bluegrass thatch cellulose and lignin content as influenced by Lawn Restore (LK), Lawn Rx (RX), and C-50. Data are the means of three observations. Values reflect the percentage by weight of each component.

forced-air oven. After drying, the samples were stored in darkness in plastic bags at $25 \mathrm{C}$ until analyses could be performed. No cultural practice was performed far 5 days before sampling and no irrigation was supplied for 2 days before sample collection.

Verdure and aerial stem tissue were cut off with shears to the leaf remnants or pseudothatch (Beard, 1973) and discarded. Root tissue and soil were removed by scraping with a knife upward to the first visibly distinct rhizome layer. Remaining mass was considered thatch for thickness measurements. To obtain a measure of uncompressed thickness, each sample was measured with a vernier caliper at five equidistant points around the circumference. Values within a sample were averaged, then sample means were averaged to provide plot means for statistical analysis. Before chemical analysis, thatch was ground with a Wiley mill to pass 40 mesh, dispersed in warm (i.e., 75 to 80C), distilled water for $10 \mathrm{sec}$ in a Waring blender, sieved on a 150-mesh screen, then redried for $8 \mathrm{hr}$ at $100 \mathrm{C}$. Material retained by the sieve was used in the analytical procedures. Fiber analysis was performed on duplicate samples of a composite sample from each plot (USDA, 1970). Data values were averaged to provide plot means.
On 20 Nov. 1985, three additional 10.8 $\mathrm{cm}$-diameter samples per plot were collected to a depth of $10 \mathrm{~cm}$ for earthworm (Lumbricus spp. Hoff.) counts. Verdure was removed from fresh samples to the pseudothatch, and root tissue/soil was removed as described and discarded. Earthworms residing in the thatch were extracted with $0.025 \%$ formalin (Walther, 1984) and counted. Samples were also picked apart by hand to ensure that all worms were tabulated. Earthworm numbers were then averaged to obtain plot means.

Analysis of variance was performed on plot means for all measurements. An LSD value was calculated for each set of analyses across all $\mathrm{N}$ levels to indicate what the magnitude of any possible differences might be. Trend analysis was performed on treatment means to determine the nature of response of thatch characteristics to varying levels of each material. Linear correlation coefficients and regression statements were calculated by least squares.

Thatch treated with Lawn Restore, Lawn $\mathrm{Rx}$, and C-50 was reduced in thickness when compared to untreated thatch (Fig. 1). Both material and $\mathrm{N}$ level contributed to differences, and no interactive effects were detected. Thatch depth correlated negatively with $\mathrm{N}$ level [ $\left.r=-0.91, \mathrm{Y}^{\prime}=22.5-0.02(\mathrm{X})\right]$, which conflicted with Potter's report (1985) that thatch depth in Kentucky bluegrass correlated positively with $\mathrm{N}$ level. Trend analysis showed that thatch thickness decreased linearly in response to $\mathrm{N}$ level for Lawn Restore and C-50, while a quadratic response was observed for Lawn Rx (Table 1). It was not determined what actually effected the decrease in thatch thickness.

Thatch thickness was negatively correlated with lignin content $\left[r=-0.94, \mathrm{Y}^{\prime}\right.$ $=22.3-0.43(\mathrm{X})]$ and positively correlated with cellulose content $\left[r=0.62, \mathrm{Y}^{\prime}\right.$ $=19.8+0.40(\mathrm{X})]$ (Fig. 2). Lignin accumulation likely reflected the loss of more easily degradable plant material, supporting Ledeboer and Skogley's (1967) suggestion that the more-soluble thatch carbohydrates are initially degraded, leaving high levels of recalcitrant material.

Increasing $\mathrm{N}$ also increased earthworm populations for treated thatch (Fig. 1). Earthworm population negatively correlated with thatch thickness [ $r=-0.64, \mathrm{Y}^{\prime}=$ $502-15.8(\mathrm{X})]$, which is consistent with the findings of Randell (1972). Trend analysis detected significant linear responses for both Lawn Restore and Lawn Rx, but no significant response for C-50. Inorganic $\mathrm{N}$ in the $\mathrm{C}-50$ at higher levels probably irritated the earthworms, as suggested by Potter (1985), although that was not proven.

The assumption that earthworm activity together with effects of $\mathrm{N}$ and micro-decomposers influenced thatch equilibrium in our study appears to be reasonable. This assumption, however, was not experimentally proven, since no attempt was made in this study to separate possible thatch effecters. Future research documenting thatch response to bio-organics at more traditional $\mathrm{N}$ levels, 
and to inorganic or synthetic organic $\mathrm{N}$ carriers, organic materials low in $\mathrm{N}$, materials with and without inoculum, and pesticides is called for to determine which parameters might control thatch equilibrium, and to what degree they do.

\section{Literature Cited}

Beard, J.B. 1973. Turfgrass: science and culture. Prentice-Hall, Englewood Cliffs, N.J.

Engle, R.E. and R.B. Alderfer. 1967. The effect of cultivation, topdressing, lime, nitrogen and wetting agents on thatch development in 1/4" bentgrass turf over a ten year period. Report on turfgrass at Rutgers Univ. N.J. Agr. Expt. Sta. Bul. 818:32-45.

Ledeboer, F.B. and C.R. Skogley. 1967. Investigations into the nature of thatch and methods for its decomposition. Agron. J. 59:320-323.

Martin, D.P. and J.B. Beard. 1975. Procedure for evaluating the biological degradation of turfgrass thatch. Agron. J. 67:835-836.

Murdoch, C.L. and J.P. Barr. 1976. ineffectiveness of commercial micro-organism inoculum in breaking down thatch in common bermudagrass in Hawaii. HortScience 11:488-489.

Potter, D. A., B.L. Bridges, and F.C. Gordon. 1985. Effect of nitrogen fertilization on earthworm and micro-arthropod populations in Ken- tucky bluegrass turf. Agron. J. 77:367-372.

Randell, R., J.D. Butler, and T.D. Hughes. 1972. The effect of pesticides on thatch accumulation and earthworm populations in Kentucky bluegrass turf. HortScience 7:64-65.

Sartain, J.B. and B.G. Volk. 1984. The influences of selected white rot fungi and topdressing on the composition of thatch components of four turfgrasses. Agron. J. 76:359-362.

USDA. 1970. Forage fiber analysis. Agr. Hdbk. 379.

Walther, P.B. and R.M. Snider. 1984. Techniques for sampling earthworms and cocoons from leaf litter, humus and soil. Pedobiologia 27:293-297. 